Warszawskie Studia Pastoralne UKSW

Rok XII 2017 Nr 2(35)

Ks. GRZEgorz BACHANEK

\title{
TEOLOGICZNE PODSTAWY DZIAŁALNOŚCI TRZEŹWOŚCIOWEJ KS. KAROLA MIKOSZEWSKIEGO
}

Theological foundations of pro-sobriety activities of Fr. Karol Mikoszewski

Sto trzydzieści lat temu 3 października 1886 r. zmarł w Budapeszcie ks. Karol Mikoszewski (1832-1886), jeden z działaczy ruchu niepodległościowego w okresie poprzedzającym wybuch powstania styczniowego. W 1862 r. redagował tajne pismo Głos Kapłana Polskiego. Jako członek Centralnego Komitetu Narodowego zajmował się propagandą powstańczą wśród ludności wiejskiej. W jego mieszkaniu przy parafii Św. Aleksandra w Warszawie zapadła decyzja o wybuchu powstania styczniowego.

Działalność trzeźwościową rozwinął jako wikariusz parafii Św. Aleksandra. Podjął inicjatywę wygłaszania w każdą niedzielę nauki zachęcającej do trzeźwości. Na nauki przybywali także wierni z innych parafii. Wyrzekających się pijaństwa zaczął zapisywać do specjalnej księgi i zobowiązywał do comiesięcznych spotkań ${ }^{1}$. Dążył do powołania pierwszego w Warszawie bractwa trzeźwości.

W roku 1862 opublikowany został wybór kazań Mikoszewskiego na temat trzeźwości. Warszawska prasa, m.in. Gazeta Warszawska, oceniła je pozytywnie. Autor planował wydanie kolejnych nauk, poświęconych wspomnianemu problemowi, wygłaszanych tym razem podczas nieszporów. Plany te nie zostały jednak zrealizowane ze względu na wybuch powstania styczniowego ${ }^{2}$.

1 Por. W trosce o trzeźwość Narodu. Sylwetki trzeźwościowych działaczy XIX wieku oraz antologia ich pism, red. M.P. Romaniuk, Warszawa 1994, s. 140-143.

2 Por. K. Mikoszewski, Pamiętniki moje, Warszawa 1987, s. 55. 
W tym artykule zostaną ukazane teologiczne podstawy nauczania ks. Karola Mikoszewskiego na temat trzeźwości. Warto pamiętać, że wspomniane kazania głosił ksiądz niespełna trzydziestoletni, który w parafii Św. Aleksandra rozwinął szeroką działalność duszpasterską, poznając różne środowiska, a w sposób szczególny ubogą ludność stolicy.

\section{Pismo Święte i głos pasterzy Kościoła}

W kazaniach ks. Mikoszewskiego znajdują się liczne odwołania do tekstów biblijnych. Pismo Święte bardzo wyraźnie ostrzega przed pijaństwem. To jeden z uczynków, który pozbawia człowieka królestwa Bożego (Ga 5, 19-21), nie pozwala mu przygotować się na dzień sądu Bożego (Łk 21, 34-35). Powoduje, że człowiek zapomina o Bogu (Iz 5, 11-12), a także prowokuje konflikty między ludźmi. Pijaństwo podstępnie niszczy człowieka, jak jad żmii (Prz 23, 29-33) ${ }^{3}$. Warto zaznaczyć, że krytyki pijaństwa nie brakuje także wśród ojców Kościoła. Przed pijaństwem ostrzegają: Augustyn, Leon Wielki, Hieronim czy Grzegorz Wielki.

Mówiąc o trzeźwości, ks. Mikoszewski odwołuje się do autorytetu pasterzy Kościoła. Papież Pius IX (†1878) uznał wartość bractw wstrzemięźliwości oraz nadał liczne odpusty kościelne zarówno osobom wyrzekającym się picia napojów spirytusowych, jak i tym, którzy przyczynili się do nawrócenia braci z nałogu pijaństwa. Jego poprzednik, Grzegorz XVI (†1846), udzielał błogosławieństwa i dziękował Bogu za rozwój działalności trzeźwościowej w świecie katolickim.

Z kolei pasterz Kościoła warszawskiego abp Antoni Fijałkowski (†1861) wydał odezwy zachęcające duchowieństwo do walki z pijaństwem oraz zalecił, by osobom składającym przyrzeczenie trzeźwości dawać do ucałowania krzyż oraz pokropić wodą święconą na znak Bożego błogosławieństwa i dla utwierdzenia w dobrym postanowieniu ${ }^{4}$.

\footnotetext{
3 Por. Kazanie na uroczystość Oczyszczenia Matki Boskiej, jako patronki wstrzemięźliwości, w: K. Mikoszewski, Kazania o pijaństwie, Warszawa 1862, s. 128-129. Zwięzłe ujęcie problematyki trzeźwości w Piśmie Świętym spotykamy w pracy M.P. Lisowskiego. Por. M.P. Lisowski, Cnota trzeźwości i trzeźwościowa formacja w Kościele, w: Bądźmy trzeźwi, Warszawa 1982, s. 113-116.

4 Por. Kazanie z Ewangelii na uroczystość Matki Boskiej Gromnicznej, Patronki wstrze-
} 
Nie można zapomnieć o następcy Fijałkowskiego abp. Zygmuncie Szczęsnym Felińskim, który przybył do Warszawy 9 lutego 1862 r. i w krótkim czasie swojego pasterzowania podjął zdecydowaną walkę z pijaństwem. W tym celu zreformował bractwa trzeźwości, ogłosił dla nich jednolite przepisy, wzywał naród do trzeźwości, zachęcał kapłanów do gorliwej pracy w tej dziedzinie ${ }^{5}$. Abp Feliński dostrzegał społeczne znaczenie trzeźwości, jej wartość dla rodziny i narodu. Nawet jeśli nie udaje się całkowicie zwalczyć pijaństwa, twierdził, to ważna jest jasna ocena moralna tego zjawiska w społeczeństwie ${ }^{6}$.

\section{Pijaństwo jako zniewaga samego Boga}

Każdy grzech, będący odrzuceniem Bożego prawa, stanowi zniewagę samego Boga. Pijaństwo jednak w szczególny sposób obraża Stwórcę, gdyż człowiek rujnuje przymioty swojej nieśmiertelnej duszy, odrzuca rozum, za pomocą którego miał poznawać Boga, osłabia wolę, traci poczucie wstydu przed czynieniem zła, niszczy swoje ciało, skraca swoje życie, czyni się niezdolnym do pracy, staje się tyranem i gorszycielem dla swoich domowników, nieprzyjacielem własnego mienia ${ }^{7}$. Pismo Święte ukazuje pijaństwo jako wielki grzech wobec Boga: Biada wam, którzy wstajecie rano, aby się oddawać opilstwu $i$ pić az do wieczora, aby się winem rozpalać... wino na biesiadach waszych, a na sprawe Pańska nie patrzycie... Biada wam, którzy jesteście mocnymi $w$ piciu wina, i mężami dzielnymi $w$ mieszaniu opilstwa... Dlatego zapalczywość Pańska rozgniewata się na lud Jego... .

\section{Godność człowieka jako motyw trzeźwości}

Człowiek jest najszlachetniejszym dziełem Stwórcy. Przewyższa godnością inne stworzenia. Tylko on spośród ziemskich stworzeń cieszy

mięźliwości, w: K. Mikoszewski, Kazania o pijaństwie, dz. cyt., s. 77. Por. Kazanie z Ewangelii na Niedziele pierwsza po Bożem Narodzeniu, w: K. Mikoszewski, Kazania o pijaństwie, dz. cyt., s. 36-37.

5 Por. T.A. Frącek, Zestaniec nad brzegami Wotgi. Miniatury z życia abp. Zygmunta Szczęsnego Felińskiego 1822-1895, Wrocław 2013, s. 255n.

$6 \quad$ Por. Z. Szczęsny Feliński, Pod wodza Opatrzności, Warszawa 2010, s. 66.

7 Por. IV Kazanie, w: K. Mikoszewski, Kazania o pijaństwie, dz. cyt., s. 43-47.

8 Iz 5, 11-12.22.25. Pismo święte Starego i Nowego Testamentu, przekł. J. Wujek, Kraków 1962. 
się rozumem i wolną wolą. Jednak, gdy człowiek odrzuca Boży dar rozumu, ulegając swoim zachciankom, spada na najniższy szczebel ziemskich stworzeń. Gdy zagłusza w sobie sumienie, dopuszcza się czynów zohydzających własną godnośćc 9

Ks. Mikoszewski wielokrotnie podkreślał, że napoje spirytusowe osłabiają ludzki rozum. Ten dar Boży, który człowiek otrzymał, by poznawać Boga, rozważać Jego dobrodziejstwa, rozpoznać swoje nieśmiertelne przeznaczenie był, jak dosadnie wyrażał się Kaznodzieja, zalewany gorzałką. Szlachetne uczucia w sercu człowieka ulegają zagłuszeniu. Pijak przestaje myśleć o żonie i dzieciach, o ich wychowaniu i zabezpieczeniu losu, o nędzy, którą na nich sprowadza. Budzą się w nim pragnienia występków, szerzy się nierząd, rodzą się zbrodnie. Duszę stworzoną na obraz Boga i przeznaczoną do mieszkania z aniołami straszny i haniebny nałóg pijaństwa odziera z godności i strąca w piekielne przepaście ${ }^{10}$.

Wcielenie ukazane jest jako podstawa godności człowieka. Tajemnica Wcielenia Syna Bożego stanowi wezwanie do szacunku wobec własnego ciała. Przyjęcie przez Boga ludzkiego ciała umacnia nas i obdarza godnością. Cierpienie i śmierć Chrystusa na krzyżu ukazują nam wielkość ludzkiej duszy, dla zbawienia której Syn Boży podejmuje dzieło odkupienia. Syn Boży, zstępując na ziemię, nie przyjął postaci anioła, ale człowieka. Stał się naszym bratem. Obdarzeni tak wielką godnością, przypominał ks. Mikoszewski, nie możemy jej poniżaćc ${ }^{11}$.

W zwróceniu uwagi na godność człowieka, stworzonego przez Boga, którego naturę przyjął Jednorodzony Syn Boży, można dostrzec ujęcie bliskie współczesnym. U progu przemian sierpniowych Jan Paweł II w swojej modlitwie o odnowę moralną narodu woła do Maryi: Ucieczko grzesznych, ulecz nasze sumienia, daj nam poznać wszystkie nasze winy, wielkie i małe. Pomóż zerwać z grzechem i obojętnościq...

\footnotetext{
9 Por. VII Kazanie, w: K. Mikoszewski, Kazania o pijaństwie, dz. cyt., s. 85-86.

10 Por. Kazanie na uroczystość Oczyszczenia Matki Boskiej, jako patronki wstrzemięźliwości, art. cyt., s. 127-130.

11 Por. Kazanie z Ewangelii na Boże Narodzenie, w: K. Mikoszewski, Kazania o pijaństwie, Warszawa 1862, s. 27-28.
} 
Daj opamiętanie nietrzeźwym, którzy tak poniżaja w sobie godność czlowieka i marnuja wspólne dobro Narodu ${ }^{12}$.

\section{Pragnienie odrodzenia ojczyzny}

Ks. Mikoszewski często odwoływał się do patriotyzmu, do narodowej dumy związanej z wielkimi postaciami polskiej historii, w której nie brakuje wielkich świętych, uczonych, poetów, królów czy dowódców wojskowych. Wskazywał na dumę, bazującą na życiu i działalności takich osób, jak św. Jadwiga, Mikołaj Kopernik, Jan Kochanowski, Stefan Batory czy Jan Karol Chodkiewicz. Jednak chlubieniu się przed sobą i światem tym, co wielkie i piękne, towarzyszy głęboki wstyd z powodu naszych nałogów, w szczególności pijaństwa. Ono stało się jedną z przyczyn, która przywiodła do upadku polski naród. Dostrzegając polskie nałogi, cudzoziemcy reagują śmiechem, lekceważeniem i wzgarda ${ }^{13}$. Autor zwraca uwagę na francuskie powiedzenie: Pijany jak Polak, którym obcokrajowcy opisują człowieka pijanego na ulicy. Podkreśla w ten sposób poniżenie narodu, który utopił w popularnej gorzałce swoją dawną wielkośćc ${ }^{14}$.

W okresie świetności Rzeczpospolitej wódka była prawie nieznana, a przodkowie nasi odznaczali się dzielnością, niezłomnością charakteru, podniosłością ducha, mocą i siłą ciała. Pokazywali w ten sposób, że powstrzymanie się od trunków jest możliwe i przyczynia się do zdrowia duszy i ciała ${ }^{15}$. Niektórzy historycy potwierdzają, że w Polsce umiejętność destylacji pojawiła się na przełomie XVI i XVII wieku, a wcześniej pito przede wszystkim niskoprocentowe piwa, miody; wina - w przypadku najzamożniejszych. Gorzelnie pojawiają się masowo na terenie Polski dopiero w początkach wieku XIX ${ }^{16}$.

\footnotetext{
12 Jan Paweł II, Modlitwa o odnowe moralna Narodu, w: Jan Paweł II, W trosce o trzeźwość człowieka, red. M.P. Romaniuk, Warszawa 2008, 115-116.

13 Por. Kazanie z Ewangelii na niedziele czwarta Adwentu, w: K. Mikoszewski, Kazania o pijaństwie, dz. cyt., s. 11-18.

14 Por. Kazanie na uroczystość Oczyszczenia Matki Boskiej, jako patronki wstrzemięźliwości, art. cyt., s. 131.

15 Por. Kazanie na Niedzielę Starozapustna, w: K. Mikoszewski, Kazania o pijaństwie, dz. cyt., s. 54-55.

16 Por. K.D. Moczarski, Historia alkoholizmu i walki z nim, w: W trosce o trzeźwość narodu. Sylwetki najwybitniejszych działaczy trzeźwościowych XIX i XX wieku oraz
} 
Miłość ojczyzny była dla Kaznodziei jednym z ważnych motywów walki z nałogiem. Ojczyzna, która żywi i utrzymuje, przechowuje cenne pamiątki z przeszłości, przechowuje szczątki przodków, nie może i nie powinna być obojętna dla jej mieszkańców ${ }^{17}$. Chrześcijanin nie jest jednostką odizolowaną od innych. Jest wezwany do braterskiej miłości i stanowienia jednej rodziny. Stąd wynika odpowiedzialność za braci oddających się nałogom poniżającym godność człowieka i obrażających majestat Boga ${ }^{18}$. Autor poprzez swoją działalność trzeźwościową dążył do moralnego odrodzenia kraju. Pragnął, by włączyli się $\mathrm{w}$ to dzieło także inni kapłani, by bractwa trzeźwości zaczęły działać również w Warszawie ${ }^{19}$. Nie jest dziełem przypadku fakt, że ruch trzeźwościowy $\mathrm{w}$ stolicy zaczyna rozwijać się $\mathrm{w}$ okresie ożywienia patriotyzmu ${ }^{20}$.

Ks. Mikoszewski postrzegał w trzeźwości jej wielkie znaczenie dla rozwoju oświaty i ekonomii. Twierdził, że w Polsce można znaleźć tysiące wiosek i wiele miasteczek, w których nie ma żadnej szkoły, nawet najuboższej kaplicy, ale wszędzie jest karczma. A przecież wydatki przeznaczane na alkohol wystarczyłyby na poprawienie bytu materialnego, na utrzymanie nauczyciela, na wychowanie dzieci, by mogły nauczyć się czytać i pisać, poznać Boga i swoje obowiązki ${ }^{21}$. Wielkie zadanie stoi przed młodzieżą, która może stać się ozdobą narodu i chwałą przyszłej wielkości naszej ziemi ${ }^{22}$.

Duszpasterz parafii Św. Aleksandra w szczególny sposób czuł się odpowiedzialny za mieszkańców Warszawy. Patrzył na nich krytycznie. Dostrzegał wielu, którzy nie chodzili do kościoła, nie znali Boga, weszli na drogę pijaństwa i występków. Szkicował przed słuchaczami

\footnotetext{
antologia ich pism, t. IV, red. M.P. Romaniuk, Warszawa 2007, s. 282.

17 Por. Kazanie z Ewangelii na niedziele czwarta Adwentu, art. cyt., s. 12-13.

18 Por. Kazanie z Ewangelii na Boże Narodzenie, art. cyt., s. 28-29.

19 Por. K. Mikoszewski, Kazania o pijaństwie, dz. cyt., s. 6-7.

20 Na związek dominujących trendów kulturowych z etiologią i odpornością na uzależnienia zwraca uwagę M. Dziewiecki. Por. tenże, Etiologia i profilaktyka uzależnień w perspektywie integralnej, w: O godność osoby ludzkiej, Radom 2002, s. 124-131.

21 Por. Kazanie z Ewangelii na uroczystość Matki Boskiej Gromnicznej, Patronki wstrzemięźliwości, art. cyt., s. 70-72.

22 Por. Kazanie na uroczystość Matki Boskiej Oczyszczenia Patronki Wstrzemięźliwości, art. cyt., s. 120.
} 
smutny widok niektórych miejsc Warszawy, gdzie gromady pijanych dopuszczały się kłótni, obrzucały obelgami, rozpoczynały bijatyki. Służący i wyrobnicy tracili w szynkach znaczną część swojego zarobku. Byli nakłaniani do okradania swoich panów, by zdobyć środki na alkohol. Młode dziewczyny traciły niewinność. Rzemieślnicy w pogoni za zarobkiem przestawali rzetelnie pracować i tracili zaufanie swoich klientów. Pracownicy warsztatów i fabryk, zaniedbując swoje obowiązki w poniedziałki i wtorki, musieli kończyć prace $\mathrm{w}$ niedziele i święta. Ufni mocy Chrystusa, wołał Kaznodzieja, miejmy jednak nadzieję na pozyskanie i tych grzeszników nałogowo oddających się pijaństwu. Wielu już nawróciło się, wielu przy trybunale pokuty błaga Boga o przebaczenie.

Jakże inaczej, twierdził Duszpasterz, będzie wyglądała Warszawa, gdy przyjmie zasady wstrzemięźliwości. Trzeźwy człowiek przynosi do domu pokój. Żona i dzieci mogą doznać ojcowskiej miłości i troski. Trzeźwy może wstać następnego dnia wczesnym rankiem, aby z rzetelnością i sumiennością podjąć swoje zawodowe obowiązki. Poprzez pracę poprawia swój byt materialny, umożliwia swoim dzieciom edukację, w jego życiu pojawia się spokój i zadowolenie ${ }^{23}$.

\section{Odpowiedzialność za rodzinę}

Nałóg pijaństwa dotkliwie uderza w rodzinę. Cierpi żona, zmuszona mieszkać pod jednym dachem z mężem pijakiem, mąż, któremu żona swoim pijaństwem zatruwa życie, dzieci, które muszą patrzeć na poniżenie swoich rodziców ${ }^{24}$. Autor, chociaż ukazuje pijaństwo jako przede wszystkim wadę mężczyzn, wskazywał także na problem pijących żon i matek. Zachęcał rodziców do podejmowania trudu wychowania swoich dzieci tak, by nie wyrosły one na hańbę rodziców, by społeczeństwo nie musiało się przed nimi bronić kajdanami i więzieniem.

W trosce o trzeźwość dostrzegał ważną rolę kobiety, będącej wzorem pobożności umacniającej mężów i synów w przywiązaniu do wiary ojców ${ }^{25}$. Kaznodzieja, podkreślając głęboką wiarę polskich matek

23 Por. Kazanie na Niedzielę Starozapustna, art. cyt., s. 58-65.

24 Por. Kazanie z Ewangelii na Niedziele pierwsza po Bożem Narodzeniu, art. cyt., s. $38-39$.

25 Por. Kazanie z Ewangelii na uroczystość Matki Boskiej Gromnicznej, Patronki wstrze- 
i prababek, z bólem zauważał współczesną nieznajomość nauki wiary i jej lekceważenie ${ }^{26}$. Wskazując na wartość trzeźwości, autor wymieniał fundamentalne cechy mające podstawowe znaczenie dla życia rodziny: pokój, zgoda, mitość, dostatek domowy, podniesienie moralne ${ }^{27}$.

\section{Wezwani do wiecznego życia w Bogu}

Mikoszewski zwracał uwagę na przemijalność ludzkiego życia. Jak mija bezpowrotnie stary rok, przemija wszystko, co ziemskie, tak przeminie życie doczesne człowieka. Wielu z tych, mówił, którzy rok temu modlili się z nami, nie ma już wśród nas. Nie wszystko jednak przemija. Jest $\mathrm{w}$ istocie ludzkiej coś nieśmiertelnego, trwającego na wieki. W życiu ludzkim istnieją dwie drogi. Wąska, prowadząca do celu, do którego Bóg powołuje człowieka, by mógł cieszyć się wiecznym szczęściem i szeroka, wygodna, nakreślona przez szatana, świat i występne namiętności ludzkie, prowadząca do wiecznego potępienia. Zbawczą drogę życia ukazuje Jezus Chrystus, Bóg-człowiek, gwiazda przewodnia ludzkości.

U progu nowego roku, stwierdzał Kaznodzieja, patrzymy na nasze życie, na walkę o trzeźwość, którą rozpoczęliśmy w parafii. Kościół raduje się tymi, którzy podjęli uroczyste przyrzeczenia zachowania cnoty wstrzemięźliwości i w niej wytrwali. Podejmujący to dzieło moga być wzorem i przykładem dla nieszczęśliwych braci pogrążonych w nałogu. Nad tymi, którzy nie wytrwali w trzeźwości, Kościół płacze i niesie przebaczenie, wzywa do spowiedzi, do przemiany życia, nie zamyka przed nimi macierzyńskiego serca, udziela pomocy. Nowy Rok to czas podjęcia walki moralnej, to czas dziękczynienia za życie i świat, którego pięknem możemy się cieszyć. Życie nasze zostało przedłużone, by mocniej rozrosło się w Bogu ${ }^{28}$.

\footnotetext{
mięźliwości, art. cyt., s. 71, 76.

26 Por. Kazanie na Oczyszczenie Matki Boskiej jako patronki wstrzemięźliwości, art. cyt., s. 126.

27 Por. Kazanie z Ewangelii na uroczystość Matki Boskiej Gromnicznej, Patronki wstrzemięźliwości, art. cyt., s. 76.

28 Por. Kazanie na dzień Nowego Roku, w: K. Mikoszewski, Kazania o pijaństwie, dz. cyt., s. 101-111.
} 
$\mathrm{Na}$ temat przemijalności ludzkiej egzystencji, ale jednocześnie o potrzebie przygotowania się na ucztę w Domu Ojca mówił: Przechodząc wśród mogił na Powązkach, uświadamiamy sobie, że świat nie zaspokoi pragnień naszego serca. Jest on tylko miejscem chwilowego pobytu, drogą ku nieśmiertelności. Towarzyszy nam w podróży, jaką odbywamy wśród fal upływającego czasu, ale nie powinien być celem naszych dążeń. Sam Chrystus przygotował dla nas ucztę w ojczyźnie niebieskiej. Aby w niej uczestniczyć, potrzebny jest nowy strój, szata godowa. Potrzeba jest również oświecenia umysłu prawdami religii i skłonienia serca do miłości rzeczy świętych. W wysiłku nad podniesieniem się z moralnego upadku wielkie znaczenie ma usunięcie źródła niemoralności, jakim jest pijaństwo ${ }^{29}$.

\section{Czy Chrystus narodzi się i w moim sercu?}

Czas adwentu, wskazywał Mikoszewski, to czas pokuty i poprawy życia, zdecydowanego opowiedzenia się za Chrystusem, przygotowania się, by mógł On narodzić się i w naszych sercach. Jest to więc czas walki z nałogami, poddania namiętności Bożemu prawu. W tym czasie przyzywamy mocy Boga, by Jego łaska umocniła nas w cnocie umiarkowania i wstrzemięźliwości jako podstawie podniesienia się do $\mathrm{Boga}^{30}$. Pragniemy godnie przyjąć naszego Pana i Zbawcę. Potrzebujemy szczerości, prostoty i niewinności pasterzy witających Jezusa w Betlejem, świętości aniołów. By godnie obchodzić uroczystość Bożego Narodzenia, powinniśmy odrzucić berło szatana, grzechu, namiętności i złych nałogów. Szczególne znaczenie ma odrzucenie nałogu pijaństwa, który jest źródłem wszystkich nieszczęśćc ${ }^{31}$.

Za lekarstwo na ludzkie niedoskonałości Mikoszewski uważał miłość Boga i odpowiedź na nią ze strony człowieka. Głosił: Krzyż Chrystusa potrafi zmiękczyć najtwardsze serca. Patrząc na krzyż, na Chrystusa, który składa za mnie największą ofiarę ze swego życia, na przebite mieczem serce Jezusa otwarte dla każdego, dostrzegam jak Bóg mnie kocha, jak miłuje każdego z nas. Wobec tak wielkiej miłości

29 Por. Kazanie z Ewangelii na Niedzielę XIX po Świątkach, w: K. Mikoszewski, Kazania o pijaństwie, dz. cyt., s. 91-97.

30 Por. Kazanie z Ewangelii na niedziele czwarta Adwentu, art. cyt., s. 10-11,19.

31 Por. Kazanie z Ewangelii na Boże Narodzenie, art. cyt., s. 21-26. 
cóż znaczy tak niewielkie poświęcenie, jakim jest wyrzeczenie się wódki. Ile razy przyjdzie chwila pokusy, warto spojrzeć z wiarą na krzyż zawieszony na naszych piersiach ${ }^{32}$. Można dostrzec pewne podobieństwo w odwołaniu się do krzyża Chrystusa w działalności trzeźwościowej ks. Karola Mikoszewskiego i Karola Antoniewicza ${ }^{33}$. W obu przypadkach krzyż Chrystusa stanowi wezwanie do poświęcenia, a rozważanie Męki Pańskiej uzdalnia człowieka do podjęcia walki o trzeźwość i przeciwstawienia się pokusom.

Ze smutkiem patrzymy na pijaństwo wśród chrześcijan, dla których krzyż jest godłem już od tysiąca lat. Walka o to, by nauka Chrystusa przemieniła ludzi, trwa całe wieki. Powinniśmy jednak wciąż wytrwale pracować nad zbliżaniem się królestwa Bożego, nad pozbyciem się straszliwego nałogu pijaństwa, który jest źródłem upodlenia i nędzy. W rozważaniach Mikoszewskiego występuje jednak dyskusyjna idea, że uda się na ziemi zrealizować królestwo Boże, a życie moralne ludzi i społeczeństw stanie się zgodne z orędziem Chrystusa ${ }^{34}$.

\section{Maryja - nasza Matka i Patronka wstrzemięźliwości}

Stowarzyszenia, które powstały dla ratowania ludzi ulegających nałogowi pijaństwa, odwołują się do imienia Maryi i obchodzą swoje święto w dzień Matki Boskiej Gromnicznej - Oczyszczenia Matki Bożej. Ona jest Matką i Patronką wstrzemięźliwości. W dzień tego święta ci, którzy podjęli przyrzeczenie wstrzemięźliwości odnawiają przyrzeczenie wytrwania w tym stanie aż do śmierci. Dziewica Maryja przynosi Jezusa Chrystusa, światłość świata. Tego, który ratuje ludzkość pogrążoną w moralnej ciemności.

Maryja pełna łaski, obraz doskonałej ludzkości, ideał kobiety, ukazuje wzór wierności prawu Bożemu. Poddaje się temu prawu, udając się do świątyni z ofiarą, chociaż obdarzona została godnością Matki Boga i niczego nie utraciła ze swojej niewinności. Jako Gwiazda

\footnotetext{
32 Por. Kazanie z Ewangelii na uroczystość Matki Boskiej Gromnicznej, Patronki wstrzemięźliwości, art. cyt., s. 78-80.

33 Por. Kazania Ks. Karola Antoniewicza, zebrał J. Badeni, t. III: Kazania świąteczne, Kraków 1906, s. 90-91.

34 Por. Kazanie z Ewangelii na Niedziele pierwsza po Bożem Narodzeniu, art. cyt., s. $33-34$.
} 
przewodnia wskazuje wielkość powołania uczniów Chrystusa, którzy mogą porzucić grzech i namiętności, a wejść na drogę cnoty.

Mikoszewski wskazuje na związek między słabnięciem pobożności maryjnej a rozpowszechnianiem się pijaństwa. Przypomina, że pracy rzemieślników, służących i wyrobników towarzyszyły pieśni i Godzinki śpiewane ku czci Maryi. Odejście od tej tradycyjnej, porannej modlitwy, towarzyszącej ludzkiej pracy, otworzyło miejsce przekleństwom, kłótniom i pijaństwu. Tym niemniej gromnica w ręku wiernych jest znakiem, że miłość do Maryi nie ustała całkowicie. Maryja patrzy na potomków tych, którzy ją tak kochali, chcąc ich przyjąć i obdarować królewskimi darami ${ }^{35}$.

Ona pragnie naszego zbawienia - mówił. Doświadczenie historyczne pokazuje, że powrót do Boga i wiary, porzucenie złego i występnego życia najłatwiej dokonuje się poprzez imię Maryi, wezwanie Jej opieki i ukazanie macierzyńskiej miłości ku ludziom. Mikoszewski odwołuje się do Królowej Polski, Bogurodzicy, którą naród polski zawsze czcił, pod której opieką podejmował szlachetne przedsięwzięcia. Modli się, prosząc Maryję o opiekę nad tymi, którzy ponawiają śluby wstrzemięźliwości, by łaska Boża towarzyszyła im na wszystkich drogach życia i by mogli osiągnać wieczne zbawienie. W imię Maryi napomina tych, którzy trwają w pijaństwie, wzywając ich do przemiany życia ${ }^{36}$.

\section{Moc Bożej łaski}

Każde z kazań skierowanych przeciwko pijaństwu ks. Mikoszewski rozpoczyna i kończy modlitwą. Po krótkim wstępie przyzywa mocy Boga świadomy własnej nieudolności. Prosi o światło, moc słowa i otwartość wiernych. Wzywając wstawiennictwa Maryi, Matki i Królowej, wspólnie z zebranymi modli się słowami Pozdrowienia Anielskiego $^{37}$.

Zgromadzeni w świątyni na kolanach składają przyrzeczenie trzeźwości, dotyczące abstynencji od napojów spirytusowych oraz umiaru

\footnotetext{
35 Por. Kazanie na uroczystość Matki Boskiej Oczyszczenia Patronki Wstrzemięźliwości, art. cyt., s. 116-124.

36 Por. tamże, s. 126, 134-135, 138.

37 Por. Kazanie z Ewangelii na uroczystość Matki Boskiej Gromnicznej Patronki wstrzemięźliwości, art. cyt., s. 70.
} 
w spożywaniu pozostałych napojów alkoholowych. Obiecują nie przechowywać w domu trunków, nie częstować nimi innych, nie zachęcać do picia, ale wzywać do trzeźwości. Przyzywają mocy Boga, wstawiennictwa Najświętszej Maryi Panny, anioła stróża i własnego patrona ${ }^{38}$.

Zmaganie z pijaństwem Kaznodzieja postrzegał jako walkę z szatanem. W tej walce siły człowieka pozostają niedostateczne. Niezbędna jest pomoc i łaska Boga, światło Ducha Świętego. Stąd proponował codzienną modlitwę o skruchę dla zatwardziałych w nałogach grzeszników i opamiętanie dla ludzi złej woli ${ }^{39}$.

$\mathrm{Ci}$, którzy złamali swoje przyrzeczenia trzeźwości, sprzeniewierzając się tej cnocie, mogą, zdaniem Duszpasterza, przejęci żalem, oczyścić sumienia $\mathrm{w}$ trybunale pokuty, odnowić swoje śluby i w ten sposób przygotować się na dzień sądu ${ }^{40}$. Sakrament pokuty jest tutaj ukazany jako szansa dla upadającego człowieka.

Jako przykład kraju pogrążonego w pijaństwie, który jednak dzięki działaniu Boga i wierze katolickiej powstał z upadku, Mikoszewski wskazuje Irlandię. W tym kraju, w szczególny sposób naznaczonym skutkami nadużywania alkoholu: nędzą, występkami, zbrodniami, rozpoczyna swoją działalność kapucyn o. Mathew ${ }^{41}$. Ubogi zakonnik z krzyżem w ręku podejmuje dzieło wstrzemięźliwości, zachęcając do niej duchowieństwo i świeckich, mieszkańców miast i wsi. Nie tylko ludzie prości, ale i wielcy panowie, najznaczniejsze damy składają przyrzeczenie wyrzeczenia się napojów spirytusowych. W krótkim czasie w dzieło to angażują się miliony Irlandczyków, a nawet Anglicy składają katolickiemu księdzu uroczyste, publiczne przyrzeczenie trzeź-

\footnotetext{
38 Por. tamże, s. 80-81.

39 Por. Kazanie z Ewangelii na Niedziele pierwsza po Bożem Narodzeniu, art. cyt., s. $34-35$.

40 Por. Kazanie na uroczystość Matki Boskiej Oczyszczenia Patronki Wstrzemięźliwości, art. cyt., s. 124.

41 O. Theobald Mathew (1790-1856), irlandzki ksiądz ze zgromadzenia kapucynów. W latach 1838-1842 propagował abstynencję w Irlandii i przyczynił się do radykalnego zmniejszenia osób spożywających napoje spirytusowe. W roku 1843 udał się do Anglii, a w 1849 do Stanów Zjednoczonych, gdzie w 25 stanach głosił kazania wzywające do trzeźwości. Por. I. Krasińska, Ruch abstynencki w Wielkopolsce w latach 1840-1902, „Folia Historica Cracoviensia” 2013, nr XIX, s. 251.
} 
wości $^{42}$. Autor dostrzega tutaj działanie samego Boga, posyłającego ludzi, by uratować ginący naród.

Dzieło apostolstwa trzeźwości rozwija się także w innych krajach Europy kontynentalnej, np. w Niemczech, Francji, Rosji. Dociera również na ziemie polskie, najpierw do Wielkopolski i na Śląsk, później w region Płocka i na teren niektórych powiatów guberni

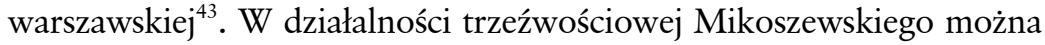
dostrzec nawiązanie do pracy Alojzego Ficka ${ }^{44}$ (1790-1862), dzięki któremu powstały na Śląsku pierwsze bractwa wstrzemięźliwości, liczące w 1844 r. już ponad 20 tysięcy członków. Ruch trzeźwości, zapoczątkowany na Śląsku, był rozwijany w Galicji i w Wielkopolsce przez ks. Karola Antoniewicza (1807-1852), organizatora bractw abstynenckich ${ }^{45}$. Ukazując rozwój apostolstwa trzeźwości, autor wskazuje na znaczenie przeżywanej we wspólnocie wiary, która umożliwia moralne odrodzenie społeczeństwa.

\section{Trzewość jako wyzwolenie z królestwa ciemności}

Chrystus przychodzi na świat, by wyzwolić człowieka z niewoli szatana. Składając cześć Zbawicielowi i zapraszając Go do naszego życia, powinniśmy wypowiedzieć walkę szatanowi poprzez odrzucenie grzechów i wykorzenianie nałogów, które nas poniżają ${ }^{46}$. Ks. Mikoszewski wzy-

42 Por. Kazanie z Ewangelii na uroczystość Matki Boskiej Gromnicznej Patronki wstrzemięźliwości, art. cyt., s. 72-75.

43 Por. Kazanie na uroczystość Oczyszczenia Matki Boskiej, jako patronki wstrzemięźliwości, art. cyt., s. 130-132. Szerzej o działalności trzeźwościowej w połowie XIX wieku duchownych diecezji płockiej pisze J. Ziółek. Por. J. Ziółek, Walka z alkoholizmem $w$ diecezji płockiej w XIX wieku, „Studia Płockie” 1986, t. XIV, s. 265-270. Ks. Mikoszewski w guberni płockiej spędził dzieciństwo, wychowując się w domu dziadków oraz uczęszczał do pierwszych szkół.

44 Ks. Ficek założył Towarzystwo a następnie Bractwo Trzeźwości. Członkowie byli zobowiązani do powstrzymania się do końca życia od używania tzw. napojów palonych (wódka, arak, rum i pochodne), umiarkowania w piciu piwa, miodu i wina, propagowania trzeźwości wśród bliskich i znajomych. Patronką całego ruchu została Matka Boża Gromniczna. Por. W trosce o trzeźwość Narodu. Sylwetki trzeźwościowych działaczy XIX wieku oraz antologia ich pism, red. M.P. Romaniuk, Warszawa 1994, s. 122.

45 Por. R. Bender, Ksiadz Karol Mikoszewski (X. Syxtus) 1832-1886, członek Rzadu Tymczasowego Narodowego 1863, emigrant, zesłaniec, Warszawa 1982, s. 19.

46 Por. Kazanie z Ewangelii na Boże Narodzenie, art. cyt., s. 24. 
wa słuchaczy, by stali się dziećmi Maryi, a nie upodlonymi niewolnikami szatana, którzy marnie spędzają czas w szynkach i knajpach, tracąc dobre imię, uczciwość, ciężko zarobione pieniądze, nie zważając na dobro rodziny ${ }^{47}$.

Wiele grzechów i zbrodni człowiek popełnia w ukryciu. W przeciwieństwie do nich pijaństwo jest złem, któremu towarzyszy bezwstyd i zachęcanie innych. Człowiek pijany próbuje wszelkimi środkami zarówno prośbą, jak i przymusem nakłaniać bliźnich do picia. W ten sposób staje się apostołem złego ducha. Pijaństwo, poprzez swój publiczny i społeczny charakter, jest grzechem szczególnie niebezpiecznym, ponieważ przez nie dokonuje się szerzenie królestwa ciemności.

Zdaniem Kaznodziei trzeba zerwać te łańcuchy, którymi szatan próbuje przykuć człowieka do siebie. Zejść z drogi prowadzącej w otchłań ciemności. W szczególny sposób powinni strzec się napojów spirytusowych ludzie młodzi, chłopcy i dziewczęta będący nadzieją przyszłości. Warto pamiętać, że nikt nie stał się od razu pijakiem, proces wchodzenia w nałóg dokonuje się stopniowo ${ }^{48}$.

Im bardziej walka z pijaństwem zaczyna przynosić rezultaty, tym mocniej niektórzy ludzie starają się temu dziełu przeszkodzić. Niektórzy potępiają wódkę, jednak bez zdecydowania i jednoznaczności. Niechęć wobec dzieła trzeźwościowego wynika przede wszystkim z troski o własny interes, chociaż próbuje się temu zaprzeczać, mówiąc o dobru ludzkości, o dobru pracujących rzemieślników ${ }^{49}$. Szeroki obraz gorzelnictwa dworskiego i wiejskich karczem w Królestwie Polskim u schyłku XIX wieku, mentalności właścicieli propinacji i gorzelników twierdzących, że działają pro publico bono, odsłania w swojej powieści Gorzatka Adolf Dygasiński $(† 1902)^{50}$. Są ludzie rozmyślnie zaślepieni, rozmyślnie wybierający złość i nieprawość,

\footnotetext{
47 Por. Kazanie na uroczystość Matki Boskiej Oczyszczenia Patronki Wstrzemięźliwości, art. cyt., s. 122.

48 Por. IV Kazanie, art. cyt., s. 47-49.

49 Por. Kazanie z Ewangelii na Niedziele pierwsza po Bożem Narodzeniu, art. cyt., s. $36,38-39$.

50 Por. W. Kotowski, Biała logika (Literaccy klasycy alkoholizmu), Ciechanów 1984, s. 21-25. Por. A. Dygasiński, Gorzatka, Warszawa 1960.
} 
próbujący nakłaniać do tego innych ludzi. Poprzez takie działanie upodabniają się do szatana. Jednak moc Boga jest większa niż moc $z \mathfrak{r a}^{51}$. Zło ma swoich obrońców, którzy złe nazywają dobrym, a zgubne zbawiennym. Mówią, że nie można się obejść bez wódki, że lud znajduje w niej orzeźwienie, że gdyby przestano używać tego napoju, to bogactwo kraju zmniejszyłoby się, a ekonomia upadłaby ${ }^{52}$.

Kazania o pijaństwie podlegały państwowej cenzurze, stąd nie mogły się w nich znaleźć uwagi o sprzeciwie caratu wobec działalności trzeźwościowej. Władze rządowe w Królestwie Polskim zakazały w 1844 r. wszelkiej działalności bractw trzeźwości. W 1857 r. władze guberni płockiej zabroniły sporządzania list wiernych zobowiązujących się do wstrzemięźliwości. ${ }^{53}$ Według ks. Mikoszewskiego działalność trzeźwościowa przyniosła obfite owoce. Pod jej wpływem tysiące mieszkańców Warszawy porzuciło picie wysokoprocentowego alkoholu $^{54}$. Niestety wikariusz Św. Aleksandra porzucił tę tak ważną inicjatywę. Przyczynił się do tego wybuch powstania styczniowego, emigracja oraz prawdopodobnie także pewne późniejsze duchowe zagubienie utalentowanego kapłana.

\section{Streszczenie}

W swojej pracy trzeźwościowej, podjętej w Warszawie przed wybuchem powstania styczniowego, ks. Karol Mikoszewski (1832-1886) wielokrotnie sięga do Bożego Objawienia i współczesnego sobie Magisterium Kościoła. Jako motyw trzeźwości szczególnie mocno uwypuklał godność człowieka stworzonego przez Boga. Często odwoływał się do patriotyzmu, wzywając do wstrzemięźliwości jako klucza odrodzenia kraju w sferze moralności, ekonomii i kultury. Odrzucenie pijaństwa, jego zdaniem, przywraca pokój i miłość w rodzinie, umożliwia właściwe wychowanie i wykształcenie dzieci. Autor mocno podkreślał przemijalność życia ludzkiego, przypominając, że jest ono skierowane ku wieczności, ale niestety może stać się także drogą ku potępieniu. Wyraźnie przywoływał osobę Jezusa Chrystusa, naszego Pana i Zbawiciela, przyjmującego ludzką naturę i składającego siebie w ofierze krzyża. Przypomi-

51 Por. Kazanie z Ewangelii na Niedziele pierwsza po Bożem Narodzeniu, art. cyt., s. 38 .

52 Por. VII Kazanie, art. cyt., s. 97.

53 Por. J. Ziółek, Walka z alkoholizmem $w$ diecezji płockiej $w$ XIX wieku, art. cyt., s. 266-268.

54 Por. K. Mikoszewski, Pamiętniki moje, dz. cyt., s. 54. 
nał, że Maryja jest Patronką wstrzemięźliwości, wzorem wierności prawu Bożemu, Królową Polski, którą należy prosić o łaskę wytrwania.

Świadomy ludzkich ograniczeń każde z kazań zaczynał i kończył modlitwą. Wraz z wiernymi prosił o wstawiennictwo Najświętszą Maryję Pannę. Jego kazania były świadectwem dobrej znajomości problemów i trosk mieszkańców Warszawy. Ostrzegał przed niebezpieczeństwem pijaństwa, które na ogół jest grzechem publicznym i łączy się z zachęcaniem, czy wręcz przymuszaniem innych do picia. Swoją działalność uważał za kontynuację dzieła irlandzkiego zakonnika o. Theobalda Mathew, dzięki któremu powstał w dziewiętnastowiecznej Europie i Ameryce szeroki ruch abstynencki. Niestety działalność trzeźwościowa ks. Mikoszewskiego trwała krótko, uległa przerwaniu.

\section{Summary}

In his work for sobriety undertaken in Warsaw before the outbreak of the January Uprising in 1863, Fr. Karol Mikoszewski (1832-1886) repeatedly referred to the Divine Revelation and the Teachings of the Church of his times. He stresses the dignity of man created by God in the context of sobriety. He reminds the importance of patriotism, as staying sober is the key to the national renewal in the area of morality, economy and culture. By rejecting drunkenness, one can restore peace and love in the family and in consequence raise and educate children adequately. The author stresses the passing away of human life and reminds that it aims for eternity but can also become a path towards damnation. He points at Jesus Christ, our Lord and Savior who accepted the human nature and sacrificed Himself on the cross. He also reminds that Mary is the Patron of sobriety and a model of fidelity to God's law. She is also the Queen of Poland whom we ask for the strength to persevere.

As the Fr. Mikoszewski is conscious of human limits, he commences and ends each sermon with a prayer. Together with the congregation he asks for the intercession Our Lady. His sermons reveal his awareness of the problems and concerns of the inhabitants of Warsaw. He warns against the danger of drunkenness which is usually a public sin and is connected to encouraging or forcing others to drink. He considers his activity to be a follow up of the actions of the Irish monk Theobald Mathew, thanks to whom a wide abstinence movement spread in nineteenth Europe and America. Unfortunately, the pro-sobriety activity of Fr. Mikoszewski lasted for a short time and was interrupted.

Słowa kluczowe: Mikoszewski Karol ksiądz, trzeźwość, pijaństwo, Polska XIX wieku, odnowa narodu, godność człowieka, Maryja Patronka wstrzemięźliwości 
Key words: Mikoszewski Karol Fr., sobriety, drunkenness, Poland in the $19^{\text {th }}$ century, dignity of a man, Our Lady Patron of Sobriety

\section{Bibliografia}

Bender R., Ksiadz Karol Mikoszewski (X. Syxtus) 1832-1886, członek Rządu Tymczasowego Narodowego 1863, emigrant, zestaniec, Warszawa 1982.

Dygasiński A., Gorzatka, Warszawa 1960.

Dziewiecki M., Etiologia i profilaktyka uzależnień w perspektywie integralnej, w: O godność osoby ludzkiej, Radom 2002, s. 117-142.

Feliński Z. Szczęsny, Pod wodzą Opatrzności, Warszawa 2010.

Frącek T.A., Zestaniec nad brzegami Wołgi. Miniatury z życia abp. Zygmunta Szczęsnego Felińskiego 1822-1895, Wrocław 2013.

Jan Paweł II, W trosce o trzeźwość człowieka, red. M.P. Romaniuk, Warszawa 2008.

Kazania Ks. Karola Antoniewicza, zebrał J. Badeni, t. III: Kazania świąteczne, Kraków 1906.

Kotowski W., Biała logika (Literaccy klasycy alkoholizmu), Ciechanów 1984.

Krasińska I., Ruch abstynencki w Wielkopolsce w latach 1840-1902, „Folia Historica Cracoviensia” 2013, nr XIX, s. 247-278.

Lisowski M.P., Cnota trzeźwości i trzeźwościowa formacja $w$ Kościele, w: Badźmy trzeźwi, Warszawa 1982, s. 113-145.

Mikoszewski K., Kazania o pijaństwie, Warszawa 1862.

Mikoszewski K., Pamiętniki moje, Warszawa 1987.

W trosce o trzeźwość narodu. Sylwetki najwybitniejszych działaczy trzeźwościowych XIX $i$ XX wieku oraz antologia ich pism, t. IV, red. M.P. Romaniuk, Warszawa 2007.

W trosce o trzeźwość Narodu. Sylwetki trzeźwościowych działaczy XIX wieku oraz antologia ich pism, red. M.P. Romaniuk, Warszawa 1994.

Ziółek J., Walka z alkoholizmem $w$ diecezji płockiej $w$ XIX wieku, „Studia Płockie” 1986, t. XIV, s. 265-270.

\section{Biogram}

Ks. dr hab. Grzegorz Bachanek - teolog, adiunkt w Katedrze Mariologii na Wydziale Teologicznym Uniwersytetu Kardynała Stefana Wyszyńskiego w Warszawie. 